\title{
Education of analgesic Balsam preparation to improve health and family economic revenue for Mabmi Binjai community
}

\author{
Effendy De Lux Putra ${ }^{1}$, Sri Yuliasmi ${ }^{1}$, Henny Sri Wahyuni ${ }^{1}$, Bayu Eko Prasetyo ${ }^{2}$ \\ ${ }^{1}$ Department of Pharmaceutical Chemistry, Faculty of Pharmacy, Universitas Sumatera Utara, \\ Medan, Indonesia \\ ${ }^{2}$ Department of Pharmaceutical Technology, Faculty of Pharmacy, Universitas Sumatera Utara, \\ Medan, Indonesia \\ *Email: effendy@usu.ac.id
}

\begin{abstract}
The Indonesian Malay Customary Community (MABMI) is one of the Malay communities in Indonesia, and one of them is located in the city of Binjai, North Sumatra. This organization has many members and is active in carrying out various activities. Members of MABMI in Binjai, who are mostly mothers and elderly (over 60 years old), often complain that they often experience health problems, especially joint pain or muscle pain, which sometimes interfere with their daily life activities. The number of MABMI members in Binjai city who work as housewives, so it is very potential if you want to do entrepreneurial activities at each home so that it can help in improving the family economy. This community service is useful in providing one of the solutions and alternatives for mothers to solve joint health problems that they often experience by providing education and training to make anti-pain balm so that the hope can be used alone if needed. In addition, the team also tried to provide stimulation for mothers who want to do business by developing this anti-pain balm preparation. Education about health products that are safe to use and further information about joint and muscle pain will also be provided by the service team.
\end{abstract}

\section{Key Words : MABMI Binjai, Balm, pain}

\begin{abstract}
Abstrak
Masyarakat Adat Melayu Indonesia (MABMI) adalah salah satu perkumpulan komunitas masyarakat melayu yang ada di Indonesia, dan salah satunya berada di kota Binjai, Sumatera Utara. Organisasi ini memiliki banyak anggota serta termasuk aktif dalam melakukan berbagai kegiatan. Anggota MABMI kota Binjai yang sebagian besar merupakan Ibu Ibu dan berusia lanjut usia (diatas 60 tahun) sehingga seringkali mengeluhkan sering mengalami permasalahan kesehatan terutama nyeri sendi atau nyeri otot sehingga terkadang mengganggu dalam melakukan aktifitas kehidupan sehari hari. Banyaknya anggota MABMI kota Binjai yang berprofesi sebagai Ibu rumah Tangga, sehingga sangat berpotensi jika ingin melakukan kegiatan wira usaha di rumah masing masing sehingga dapat membantu dalam peningkatan perekonomian keluarga. Pengabdian masyarakat ini bermanfaat dalam memberikan salah satu solusi dan alternatif bagi para Ibu ibu dalam menyelesaikan masalah kesehatan sendi yang sering mereka alami dengan memberikan edukasi dan pelatihan pembuatan Balsam anti nyeri sehingga harapannya dapat dipergunakan sendiri jika diperlukan. Selain itu, tim juga berusaha memberikan stimulasi bagi para ibu yang ingin melakukan wira usaha dengan cara pengembangan sediaan balsam anti nyeri ini. Edukasi mengenai produkproduk kesehatan yang aman digunakan dan informasi lebih lanjut mengenai nyeri sendi dan otot juga akan diberikan oleh tim pengabdian.
\end{abstract}

\section{Kata Kunci: MABMI Kota Binjai, Balsam, Nyeri}

\section{INTRODUCTION}

Binjai is one of the cities in North Sumatra that continues to develop very rapidly, both in terms of physical development and the level of economy and social life of its people. From a social perspective, 
this can be seen from the many communities or community associations that are widely available in Binjai. One such association is the Indonesian Malay Customary Community (MABMI) of Binjai city with one of the Malay ethnic backgrounds of society which is very much found in the City of Binjai. This organization has many members and is active in carrying out various activities.

Some important issues facing the association of women of the traditional council of Malay city of Binjai, North Sumatra include: 1. Mothers of the assembly in general work as housewives, with the existence of this educational activity can increase insight and knowledge and encourage / stimulate the entrepreneurial feelings of the mothers. 2. Elderly population is someone who has reached the age of 60 (sixty) years and above. In general, the elderly have a large number of problems in the health field such as joint and muscle pain. Balsam is a topical preparation that is applied to the skin and is a form of drug preparation to relieve joint pain and muscle pain that is often chosen (Zulkarnain and Aminullah, 2012). 3. If analyzed financially, the age of 60 years is the age that has entered retirement age. So that income / family income automatically decreases. So with the making of this balm, it is expected that assembly women can make balm preparations that have economic value so that it can increase family income and also increase productivity in the elderly (Indonesian Ministry of Health, 2017). 4. Educating assembly women about the right movements at work so as not to experience frequent joint and muscle pain that can be caused by errors in movement while working. Based on the author's experience who has come directly to the location around there has been no community effort to overcome minor illnesses that often suffer and efforts to increase family economic income after retirement. The need for proper weighing, the sequence of mixing systematic and sequential ingredients in order to produce a homogeneous, safe, quality and efficacious preparation by using natural ingredients that are easily obtainable in a residential environment.

\section{METHODS}

Several members of the community service team have approached and interviewed the Malay traditional assembly women housed on Jl. Jambi, Rambung Barat, South Binjai and also to the Head of the Environment and local residents, his speech was very enthusiastic by being willing to be given counseling, guidance and training in educational activities to make anti-pain balm in the context of improving health and economic opinion of this family.

Making anti-pain balm carried out in several stages of the implementation of activities, including: a. Preparation: information about potential resources, orientation to prepare the embalming to be applied, b. Socialization through meetings, conveying information about safe topical preparations and the efficacy of some traditional plants that can be used as ingredients for making balms based on their functions empirically, c. Implementation: making anti-pain balm using some basic ingredients for balm using essential oils and some traditional plants that have anti-pain properties in the joints and muscles. Give workshops on how to make health products in the form of balm. Provide education about the ingredients that will be used and the usefulness of each of these materials. What are the stages of preparation, the process of mixing to packaging will be conveyed to the Malay

\section{RESULT}

The service that has been carried out runs smoothly, both from the initial meeting with the MABMI administrators of Binjai city, the preparations made before the implementation of the workshop until the time of the counseling process and the workshop for making anti-pain balm preparations. All 
activities carried out go as scheduled. All of the participant were very excited to follow the workshop from the beginning until the end.

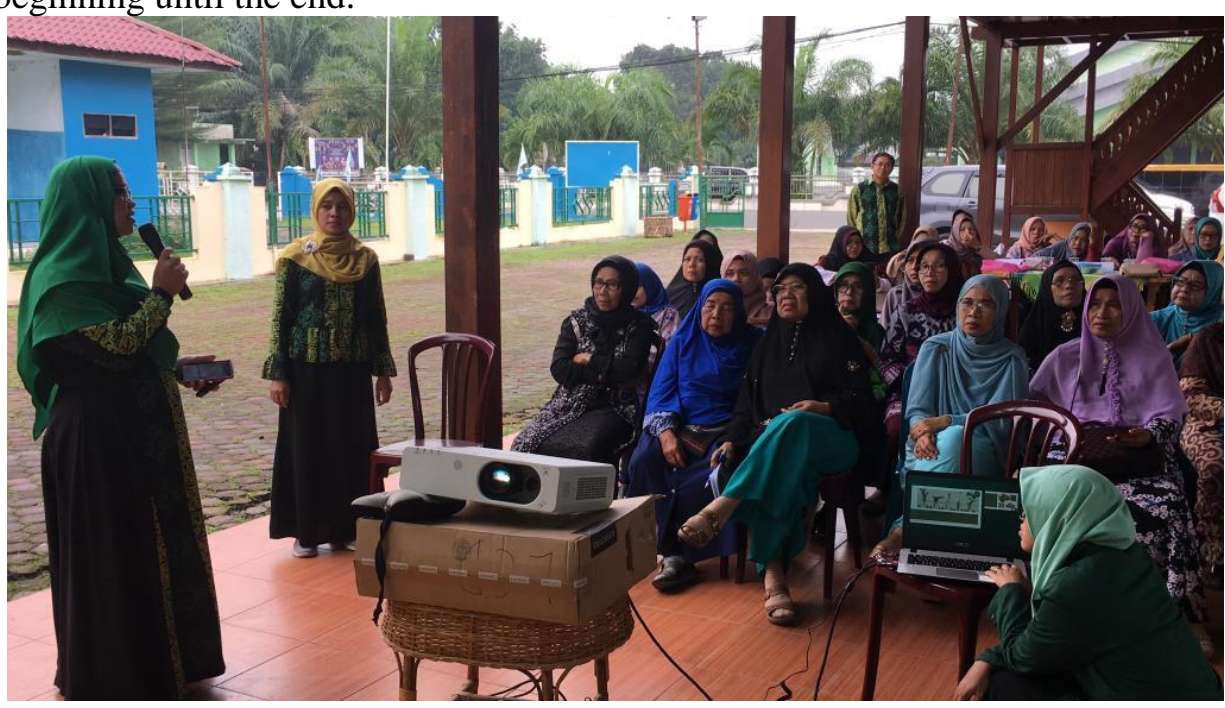

Figure 1. The Speaker given an guideline and information about the workshop

All of the participants were divided become 3 groups. Each group used the different aromatherapy oil, such as ginger, galangal and lemon grass oil. The main composition of the bal are same for all of the formulation. Because we used the different aromatherapy, it will produce the different balm odor. The participant then check the balm and choose the best formula.

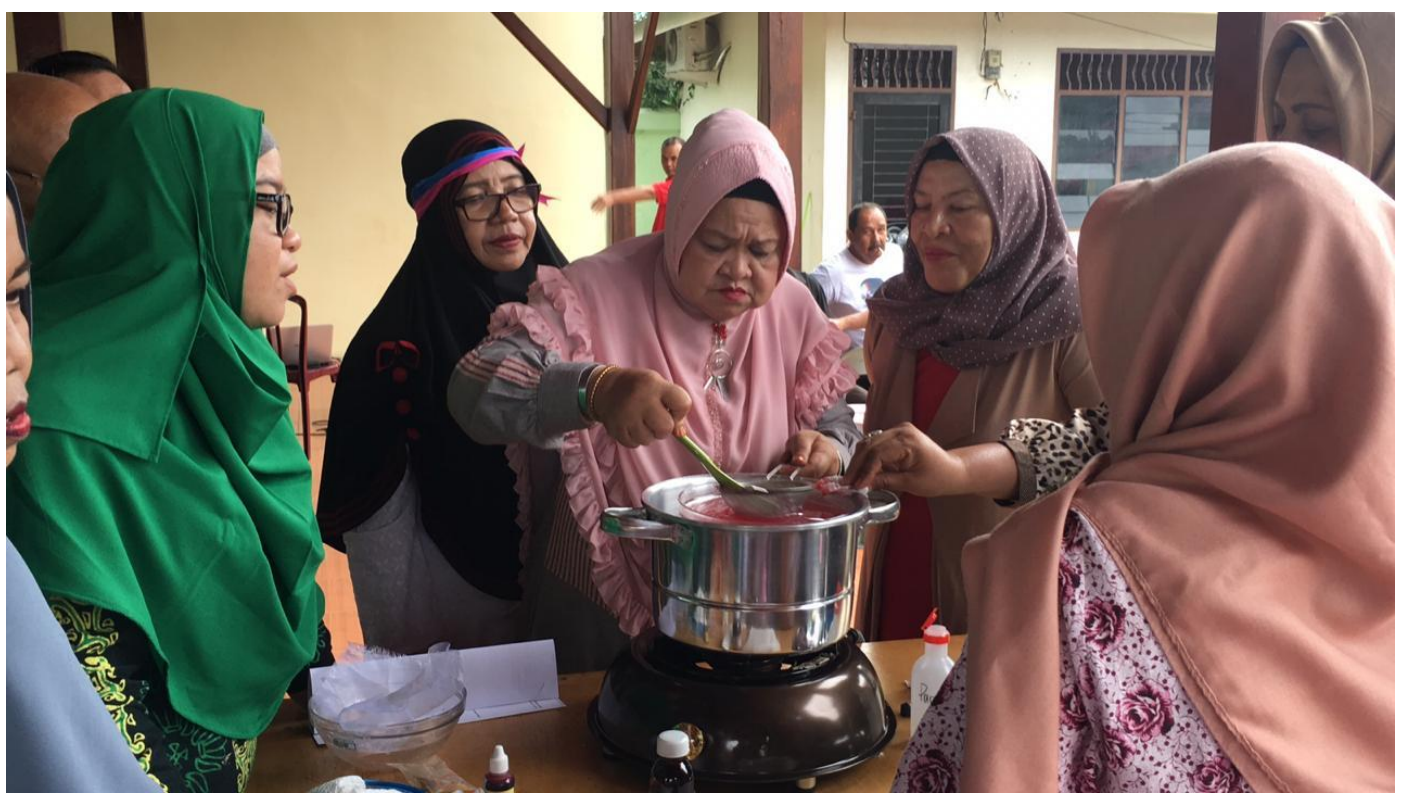

Figure 2. An participant mixed the balsam ingredient seriously 


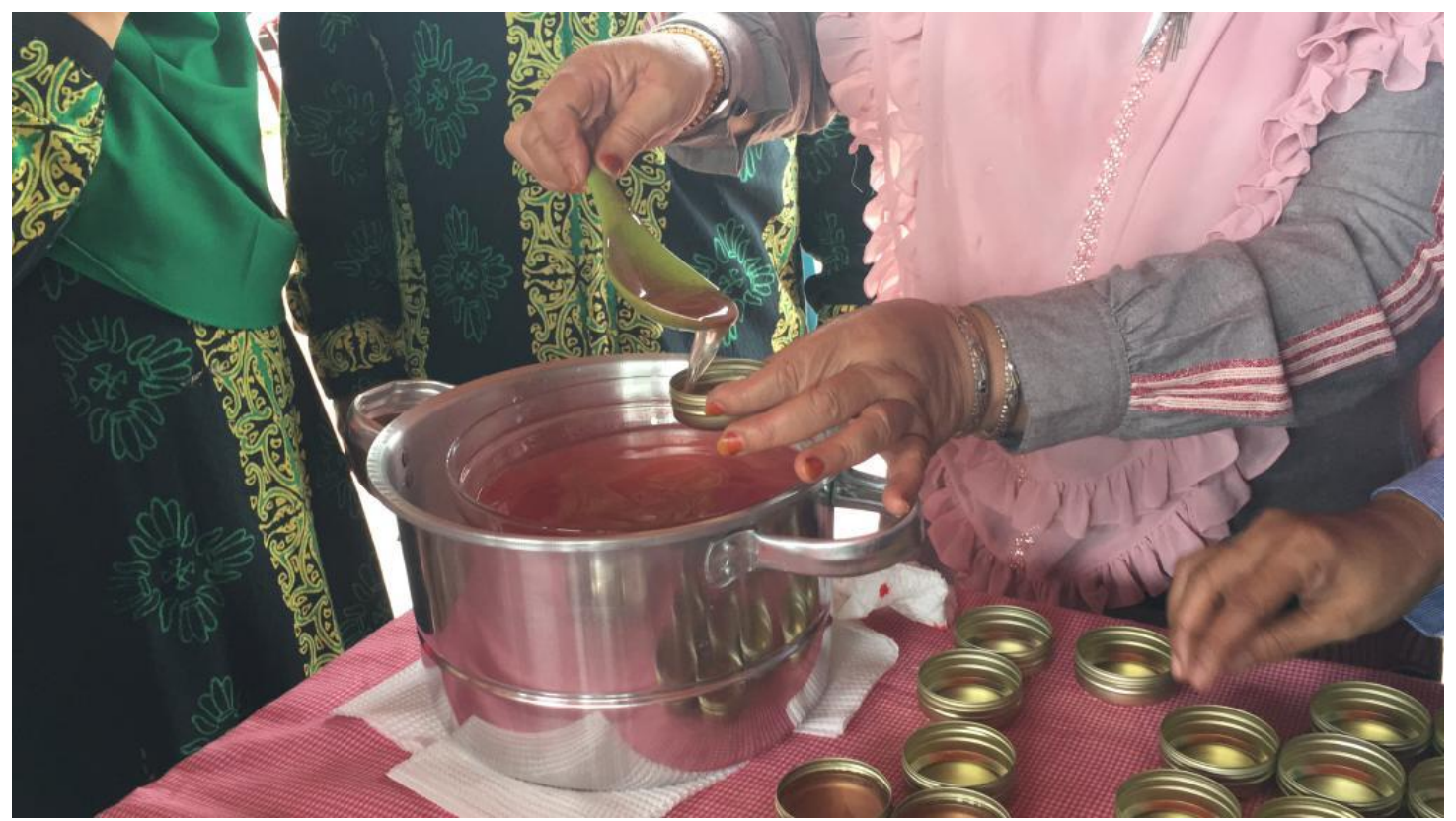

Figure 3. A participant fill the balsam adonan to the place

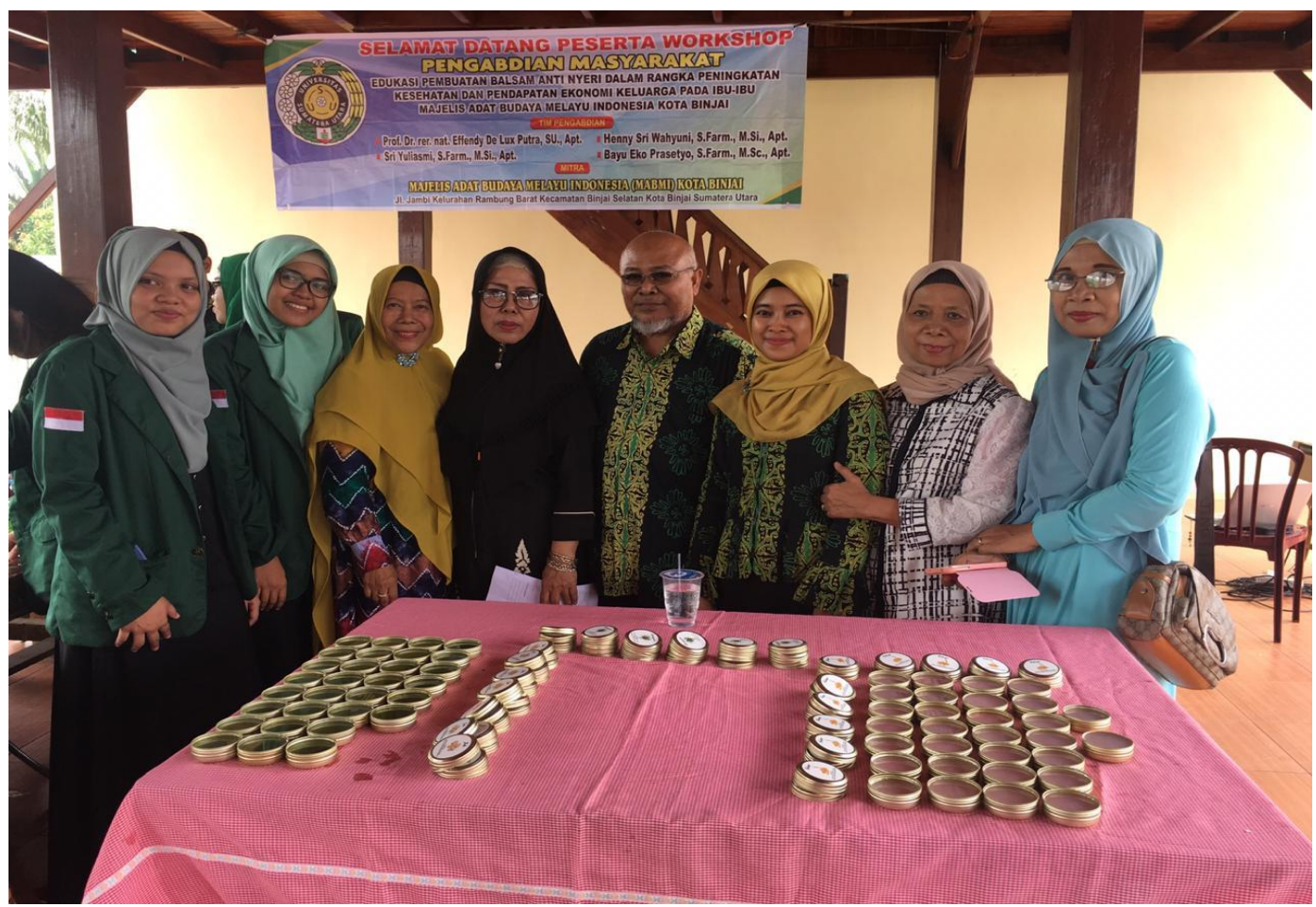

Figure 4. The team with the balm product after workshop 


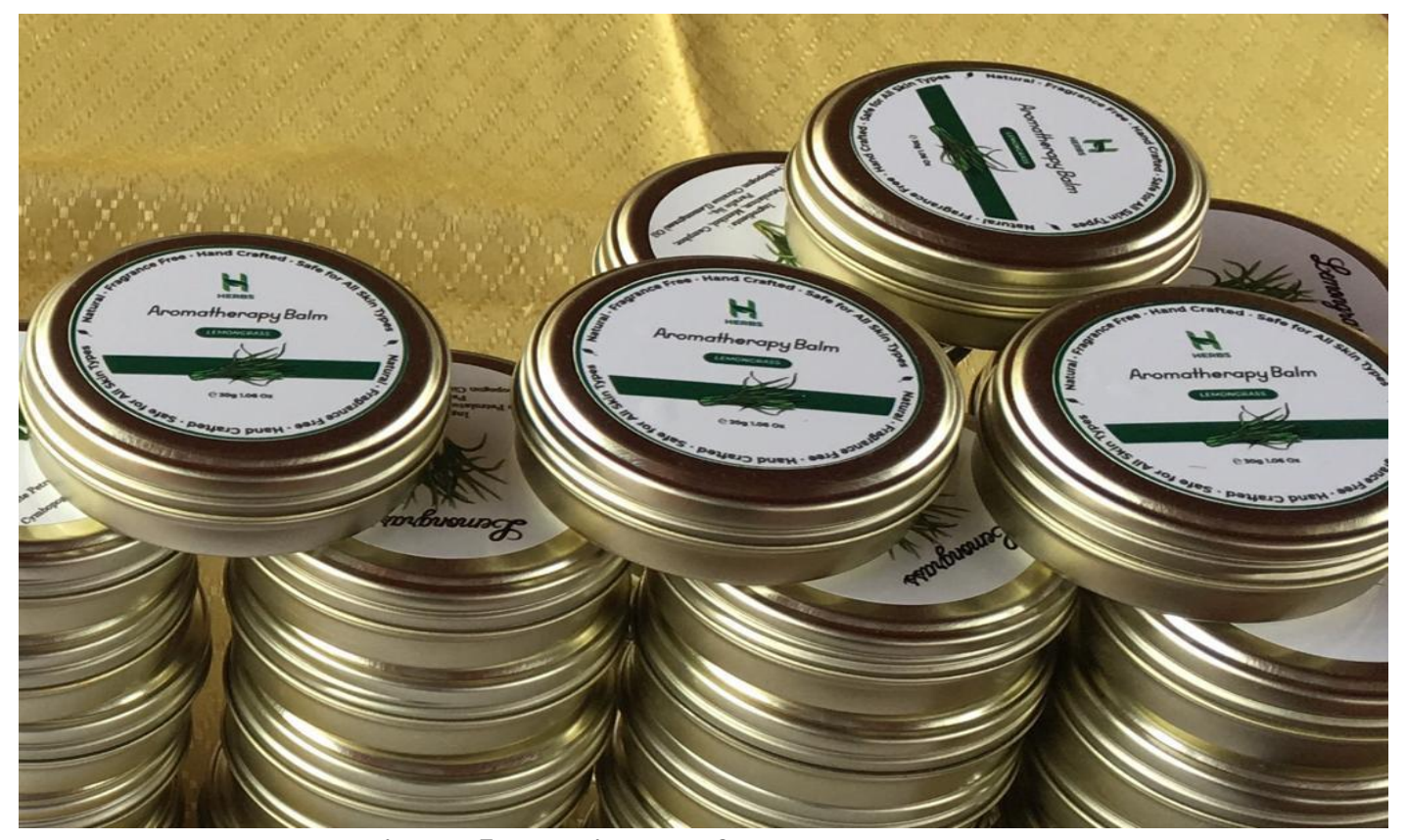

Figure 5. the picture of a ready balm to use

After that, the balm gave to the participants, so they can use the balm for their family. All of the equipment was given to the MABMI secretariat to use for the next production. Hopefully, the production of the balm can be continue, so it will be useful for the MABMI members in improve or increase their economic condition.

\section{CONCLUSSION AND SUGGESTION}

Community service in the form of education activities on the manufacture of anti-pain scent balm in the framework of improving health and economic income of the family at the Indonesian Traditional Council of the Malay Culture of Binjai City has been able to run well without significant obstacles. The active role of the resource persons who provided training, teamwork and the assistance of partners who were very cooperative were very supportive of the implementation of community service as expected. It is hoped that the community service that has been carried out can provide positive benefits, especially for community service partners in order to provide solutions to health problems for Mabmi Binjai City members, namely joint and muscle pain and of course very supportive if it is developed into an independent business so that it can help sustain family economy. The dedication that has been carried out has reached the stage of conducting training activities in making aromatherapy anti-pain balm and then we will continue until the final report on community service.

\section{ACKNOWLEDGMENT}

We would like to thank to the Rector of USU for finantial support by Mono Tahun Social Engagement Non PNBP 2019 and all participants who have helped the implementation of this Community Service. 


\section{REFERENCES}

Aisiyah, S., Harjanti, R., Nopiyanti, V., Suhartinah, Pudiastuti, R. S. P. (2016). Pemberdayaan Masyarakat dalam Pembuatan Balsam Metil Salisilat untuk Mengatasi Rasa Nyeri Sendi dan Otot Di Lingkungan Mojosongo Surakarta. Journal of Dedicators Community. Vol 01(01). Surakarta : UINSU Jepara. Halaman 76-81.

Depkes RI. (1995). Materia Medika Indonesia Jilid Ke VI. Jakarta: Ditjen POM. Hal. 297-307.

Ditjen POM. (1979). Farmakope Indonesia. Edisi III. Jakarta: Departemen Kesehatan Republik Indonesia. Hal. 8.

Evadarianto, N., dan Dwijayanti, E. (2017). Postur Kerja dengan Keluhan Musculoskeletal Disorders pada Pekerja Manual Handling Bagian rolling Mill. The Indonesian Journal of Occupational Safety and Health. Vol 06(01). Hal 97-106.

Kementrian Kesehatan RI. (2017). Analisis Lansia di Indonesia. Jakarta Selatan : Pusat Data dan Informasi. Hal 1.

Zulkarnain, I., dan Aminullah. (2012). Formulasi Minyak-Minyak Menguap Menjadi Sediaan Balsem Counterirritan. Jurnal As-Syifaa. Vol 04(01). Hal 32-41. 